\title{
APPLYING OF TEACHING MATERIALS IN TEACHING MATHS AT PRIMARY SCHOOL - GENDER ASPECT
}

\author{
Róbert Osad'an ${ }^{1}$, Eva Severini ${ }^{1}$, Veronika Valkóová ${ }^{1}$ \\ ${ }^{1}$ Comenius University in Bratislava, Faculty of Education, Department of Pre-primary and Primary Education \\ (SLOVAKIA)
}

\author{
OJPPE 3 (1) - Recenzované články/Reviewed Papers \\ Publikováno/Published dne 8. 10. 2019 \\ DOI: 10.21062/ujep/329.2019/a/2533-7106/OJPPE/2019/3/27
}

\begin{abstract}
The scientific study brings knowledge about teaching materials for teaching mathematics at the first level of primary school. It also focuses on the issue of gender and its manifestations on mathematics' lessons in primary school. Our research examined the manifestations of gender, gender stereotypes, gender-based interactions between teachers and pupils in the application of teaching materials to teaching mathematics at primary school through qualitative methodology. The research tool used is observation. The research was carried out within the grant APVV-015-3787 Optimization of teaching materials from mathematics based on the analysis of current needs and abilities of pupils of younger school age.
\end{abstract}

Keywords: Qualitative methodology, mathematics, primary school, gender, teaching materials.

\section{INTRODUCTION}

During selection and development of teaching materials for the project, it was an important aspect to provide pupils with different materials to enable them to understand mathematical concepts in different ways, as well as didactic materials that were complementary to each other. In case the development of science and technology offers continually new possibilities, also digital materials were created and used within the project which provided different types of representations compared to manual mathematical aids. There are a number of studies comparing the impact or effectiveness of manual and digital didactic materials on teaching mathematics, but their results have not shown us conclusive conclusions. Digital materials have proven to be more effective in some studies (Schacter \& Jo, 2017; Volk, et al., 2017); in other studies there was no difference in the learning outcomes of pupils using manual aids and digital materials (Moyer-Packenham, et al., 2013; Singer, 2015). For both materials we can identify different mathematical-didactic advantages (Walter, 2018).

One of the underlying theories, that emphasizes the use of diverse models and depictions in teaching, is Bruner's Theory of Representation (1966), whereby an individual goes through three stages during learning, using primarily another type of representation (enactive, iconic and symbolic representation). Digital materials create a transition between concrete and iconic representations, as interactive applications contain objects that can be manipulated (Larkin, 2016). In terms of teaching, this means using real subjects as teaching aids first, followed by activities with mathematical applications available to pupils on personal computers, interactive whiteboards or tablets.

Manual aids are used to give pupils real experience with abstract mathematical phenomena, so pupils do not have to deal with mental images and perception of phenomena they do not have sufficient experience with. Mathematical applications have various forms and focus. Applications with open tasks provide the ability to explore phenomena and allow experimentation by manipulating digital objects. As they are relocated, moved or rotated, pupils have the ability to observe changing phenomena and relationships between objects. Using such applications, by observing objects and solving graded tasks, pupils can discover mathematical relationships and principles by their own or through collaboration and discussion with classmates. Applications aimed at repeating mathematical curricula contain a series of tasks (question-answer) and can have the form of games or 
worksheets. These applications have one correct answer and they are used that provide practice and provide solution control and feedback for the learner.

Teachers have a diverse range of teaching materials available to adapt teaching to the current level of pupil development, their abilities, interests and preferences. It is important to explore the use of different types of teaching materials from different aspects, and to focus, except aspect of knowledge, also on motivation and interest as well as gender-based needs and differences between girls and boys in addition to knowledge.

\section{Gender in everyday life of primary school}

The formation of beliefs about gender role is likely to begin with an individual in early childhood, in a family, because families have the earliest and most direct influence on children's beliefs and preferences (Bisin \& Verdier, 2001). By attending primary school, in addition to their families, pupils interact simultaneously with their peers and with another adult, teacher. Teachers 'opinions on gender roles can directly or indirectly influence pupils' attitudes, behavior and performance. These beliefs can affect girls' academic aspirations, their interest in teaching subjects, such as mathematics, as well as their motivation to learn. A teacher with a strong traditional belief in gender roles may think that acquiring competencies is not so important for girls as they are unlikely to put them into practice later. Such a teacher can demonstrate these beliefs by providing different types of feedback to girls and boys, selectively answering / ignoring questions, or focusing boys during lessons (Sadker \& Sadker, 2010). Teachers' bias may also be manifested in discrimination in evaluation (against girls or in favor of girls), which may affect pupils' success and choice. In addition to directly influencing learning, such teaching practices by biased teachers can also influence long-term outcomes by influencing the development of girls' noncognitive abilities. On the other hand, a progressive teacher can put more emphasis on involving pupils in subjects that are usually considered to be the domain of the opposite gender and tries to break stereotypical attitudes in the classroom.

One of the challenges of contemporary society and the education system is solving gender inequalities in social systems (Zilcher \& Svoboda, 2019). Therefore, schools and teachers at all levels must play a key role in developing the next generation sensitive to gender equality topic (Zilcher \& Svoboda, 2018). Research suggests that teachers' personal beliefs and stereotyped perceptions affect their attitudes and classroom practice. Teachers usually believe that girls and boys are treated equally, but classroom observations suggest that this is often not the case (Spender, 1982; Younger \& Warrington, 1996; Younger, Warrington \& Williams, 1999).

An equally important aspect of research at schools is the gender impact on pupils' school success. The identified gender differences were attributed to biological and genetic determinants (Spinath et al., 2008; Hicks et al., 2008), variations in abilities and competences (Buzhigeeva, 2004; Deary et al., 2007), differences in personality characteristics (Steinmayr \& Spinath , 2008; De Fruyt et al., 2008), differences in type and level of motivation (Preckel et al., 2006; Meece et al., 2006), different attitudes to school (Buzhigeeva, 2004), different social experiences (Abraham, 1989; Lahelma, 2005), social expectations (Meelissen \& Luyten, 2008; Hyde et al., 1990), difference in self-discipline and self-regulation (Duckworth \& Seligman, 2006; Matthews et al., 2009) and difference in preferred learning styles (Carrier, 2009).

A particularly interesting explanation of gender differences in pupils' school performance is related to the dynamics of gender interaction between pupils and teachers, or more precisely, the gender combination of teachers and pupils. In addition, in recent years, the gender of the teacher - pupil and their interaction effect have become a hot topic in educational research and politics. The reason for the great interest of this topic is related to the following two facts:

- Firstly, there is prevalence female teachers at primary school in most education systems around the world. Some studies about the impact of gender of teachers in relation to their work performance emphasized that female teachers were generally more successful in teaching than their male counterparts, especially if their pupils' knowledge was measured by standardized tests. Studies organized by UNESCO showed that pupils taught by female teachers tend to perform better at school than pupils taught by male teachers (UNESCO, 2000, 2005). They were described as more sympathetic, patient, gentler and open to questions and discussion. Simpson \& Erickson (1983) and Stake \& Katz (1982) also support these findings and suggest that female teachers give more verbal and non-verbal consent to pupils than male teachers. 
- $\quad$ The second fact is that girls are now more successful in primary school than boys, even in mathematics and science, which are traditionally regarded as "male subjects" (e.g. Holmlund \& Sund, 2008; Mills et al., 2004 ). The finding that girls perform better than boys in different school subjects supports a number of other studies (e.g. Demie, 2001; Gibb et al., 2008; Duckworth \& Seligman, 2006; Ciarrochi et al., 2007; Leeson et al., 2008; Steinmayr \& amp; Spinath, 2008). Taking these two educational facts into account, some scientists linked these trends with the lack of male teachers as role models for boys (Skelton, 2003). They suggest that male teachers encourage boys to make greater efforts in school activities. Indeed, some scientists found that the gender combination of pupils and teachers has some impact on pupils' achievements at school. Dee (2006) confirmed that female pupils perform better at school when women teach them, and male pupils perform better taught by men. Ammermüller \& Dolton (2006) achieved similar results based on data from British and American primary schools.

Thus, the authors conclude that teachers' gender plays an important role in the success of pupils in higher grades, when male teachers tend to improve boys' performance in science and mathematics. However, these results were not consistent with many other studies that did not demonstrate the relevance of gender interaction between pupils and teachers in achieving pupil performance. (Francis et al., 2008; Carrington et al., 2007; Driessen, 2007; Marsh et al., 2008).

Finally, if we focus only on studies in which pupils' knowledge of the subject was measured, the type of measurement may distort the results. Looking at grades at school, girls are consistently better than boys, but it is not same when we use standardized knowledge tests (Hicks et al., 2008) The nature of school grades differs significantly from those of standardized tests. School grades partly indicate factors that are not cognitive, such as following to teachers' instructions, following rules, adaptation and order that girls favor (Carrier, 2009). Girls usually adapt better to educational activities, have a more positive attitude towards school (Resing et al., 1999), have a higher self-discipline (Duckworth \& Seligman, 2006), more effective self-regulation (Matthews et al., 2009) and less tendency to avoid work (Steinmayr \& amp; Spinath, 2008). All of these give girls an advantage in a traditional school environment and allows them to get higher grades than boys. The traditional discourse of gender studies is based on the premise that "we are not born as women and men, but we become them" because of social impacts on the individual. Although dozens of studies have shown dramatic differences in gender with respect to the brain, educational literature has not usually implemented their results and their potential relevance to education. Obviously, teachers and educators should be educated about gender differences in all areas of individual development and then build on this knowledge with the correct design of instructions and implementation teaching strategies with respect to gender differences. Based on research conducted and reviewed on gender differences, educators need to consider implementation strategies that successfully involve girls and boys in the classroom. (Bonomo, 2017):

GIRLS: • Girls work well in groups, when facing each other or the teacher. Find activities to help the teacher. • Do not protect girls from activities that could cause them to get dirty or scratch on their knees, which could encourage "learned helplessness". Safe risk activities provide girls with opportunities to reevaluate risk • Girls do not respond well to loud, sharp and short tones. They prefer softer voices. • Girls enjoy linking lessons to emotions. They respond to descriptive phrases. Loud, repetitive noise can be distracting for girls. • Do it boldly: girls prefer many colors. • Use puzzles to promote perception and symbolic learning.

BOYS: - Be brief and join them in lesson. - Encourage them with quick praise, reduce written tasks, and use models and columns that they can follow. $\bullet$ Challenge them - boys thrive in competition • Take care of boys, but let them play. Without their physical ascent, their aggressiveness will show up somewhere inappropriate. Therefore, give boys as much space as possible $\bullet$ Lessons should be kinesthetic and experiential. • Boys do not hear as well as girls, so move them closer to the instruction.

\section{METHODOLOGY}

In education, it is one of the types of scientific research in which teachers systematically examine their own didactic practice with the particular aim - improving it - practical research (action research). It is usually carried out by teachers (often in collaboration with researchers) directly within their teaching practice, where it is part of the teaching process. Action research reacts to the actual needs of didactic practice (sometimes only partial, a professional researcher does not consider, in case they are less important for him), proposes solutions that are validated directly in the teaching process, and if the outcome is effective, solutions are transferred to the teaching process. The implementation of action research is consistent with the statement that if there should be 
a conceptual change, these profound layers of the teacher's professional structure must intervene in that way, that he/she realizes: the existence of own concept (content, structure, boundaries, etc.); the need and nature of the expected changes; paths of change - real activities that will enrich or partially reconstruct elements of the original individual concept (Pavlov, 2002; Severini \& Kostrub, 2018). It should not be forgotten that pedagogical research, as applied research, is conditioned by the priority objective of helping process of reflection and criticism to improve the quality of the teaching process. Action research is targeted research conducted by a group of researchers (teachers) under the conditions of the teaching process (Kemmis \& McTaggart, 1982). It is characterized by spiral cycles of problem identification, systematic data collection, reflection, analysis, datadriven procedures and redefinition (Gil Hernández, 2007). The combination of the concepts of "action" and "research" highlights the basic specifics of this method - testing proposals for change in didactic practice as a means of gaining knowledge and / or improving the conditions of the teaching and learning process. The goal of action research, as part of the teacher's work, is to obtain practical results that can be used immediately in a didactic situation, while not excluding their contribution to the development of broader generalizations, or - as a higher degree - to the development of concepts and scientific theories.

In order to deal with the issue in our research, the methodology of qualitative research with the appropriate design was preferred: in the foreground there is a natural environment that is a direct source of data; rather, qualitative data is collected in the form of words and images; the qualitative researcher tends to analyze the data inductively; the main purpose of a qualitative researcher is to find out what meaning people give to their lives; a qualitative researcher is concerned not only with the process but also with the product of human interactions. The main features of qualitative research include intensity and longevity, detailed recording, audio or video recordings, and almost everything that happens in a particular environment is observed (Bogdan \& Biklen, 1992 In: Svec et al., 1998). Qualitative research represents the possibility of thinking about human action and thinking in different dimensions that contradict the concept of quantitative research. (Kostrub, 2016).

The research problem is the judgment of researchers arising from observation, analysis, interpretation, cultural and discursive practices in the school educational context. Within the project, on the one hand, several existing mathematical applications were tested in teaching conditions in Slovak schools, on the other hand, the project also aimed to create a set of graded mathematical applications available for primary school pupils. The mathematical applications created within the project are accessible via Internet (link to the APVV applets) and contain all accompanying texts in the Slovak language, thus support the understanding of tasks. Apps are divided into five areas, and in each area the apps are sorted according the grades. These are areas: Numbers; Numerical operations; Relations; Plane geometry; Geometry in space. Within each area, mathematical applications are created with diverse motives so pupils can choose elements based on their preferences. Several studies have shown that mathematical applications have the potential to increase pupil motivation, attract attention, and involve them to explore mathematical concepts or solve mathematical tasks (Attard \& Curry, 2012; Hilton, 2018). Examining pupils' preferences and analyzing their areas of interest provides the basis for the creation and use of teaching materials so that the teaching materials can be adapted to the interests of today's pupils and proportionate to their abilities.

The issue of gender topic, its manifestations may appear marginal in the school environment, but researches and studies show its impact on everyday life in primary school environment. The subject of our research was conversations of teaching subjects in real situations in teaching mathematics during the application of teaching materials. In our research we were therefore interested in gender differences in the learning group (class) during the applying of teaching materials to the teaching of mathematics, whether their interactions with pupils are gender-related. The decision to conduct a qualitative investigation was based on the consideration that we detect interactions that cannot be calculated, expressed as a percentage, and entered in a table. Qualitative research also suited us because it identifies the rationale and expertise of research subjects in relation to the subject (Kostrub, D., 2016, Gavora, P., 2008).

While investigating the problem, we used unstructured (direct and indirect) observation to determine the ability to use the teaching materials by examination subjects at math lessons with respect to gender. Our task was not to assess and evaluate, determine what is right, wrong, what is better or worse; we identified the interactions of subjects to the problem addressed. The research was realized at the Primary School on Sibirska in Bratislava and the Primary School of Mučín within the grant APVV-015-3787 Optimization of teaching materials from mathematics based on an analysis of current needs and abilities of younger school age pupils. Action research observations were carried out in the primary schools in the years 2016 to 2018 . The research sample was 
consisted of primary education teachers and pupils in their learning groups (classes) at the first stage of primary school during lessons of mathematics.

The method of analysis consisted in analyzing the research material (description) obtained by direct and indirect observation. Events and phenomena are considered as indicators of phenomena which is given a conceptual designation. Systematic reflection of professional situations, examination of pedagogical reality and initial diagnosis based on the evidence of pupils in the learning group preceded the examination (indirect observation). Continuous diagnostics based on the evidence of pupils in the learning group was realized during teaching process and the final diagnostics based on the evidence of pupils in the learning group was carried out during the pedagogical reflection on the realized teaching activities within the micro-teaching. The typology analysis was carried out as a phase of qualitative analysis of the research. It is a special form of description that requires cleansing of a great deal of material, analysis and massive description - these are forms of description (also in the form of reference frameworks), which can themselves help to understand the field of some social activity (Woods, 1987 In: Kostrub, 2016). A lot of research material was obtained during the research, which took the form of video recordings and pictures / photographs. In indirect observations videos of teaching activities were repeatedly played; significant elements were sought to reflect the application of teaching materials in the teaching of mathematics with respect to gender. When analyzing the findings from both direct and indirect observations, the reference framework was abstracted. The registration of the research results was evaluated on the basis of the established reference framework with evaluation comments, which were used in the interpretation of the research results.

Tab. 1 Reference framework - use of teaching materials for teaching mathematics. Source: author's own elaboration

\begin{tabular}{|c|c|}
\hline INTEGRATION & $\begin{array}{l}\text { General framework: students are independent, they do not need help. They use } \\
\text { fully teaching materials. They act freely, at their own discretion, in accordance with } \\
\text { jointly developed rules. } \\
\text { A concrete framework for action: pupils encourage subjects in the learning group } \\
\text { to activity, keep interaction in activity, end activity, self-evaluate activity, and } \\
\text { provide feedback to subjects (other classmates and teacher) about the activity. }\end{array}$ \\
\hline CONTEXTUALIZATION & $\begin{array}{l}\text { General framework: pupils start to use teaching materials on their own, act } \\
\text { independently, but not completely independent. In their actions, they turn to } \\
\text { teachers to give them concrete help. They partially use the teaching materials on } \\
\text { their own. } \\
\text { Framework of concrete action: pupils together with the teacher propose } \\
\text { conditions, during the activity they invite the teacher to help them, partially } \\
\text { evaluate the activity and, with minimal support of the teacher, they give feedback } \\
\text { on the activity. }\end{array}$ \\
\hline DECONTEXTUALIZATION & $\begin{array}{l}\text { General framework: pupils learn to act independently. They alternate assistance } \\
\text { from a teacher with own actions and this is verified by reassuring questions. } \\
\text { Gradually, they start to use teaching materials on their own. } \\
\text { A concrete framework for action: pupils try to use the teaching materials on their } \\
\text { own, but call teacher to provide feedback on their actions. They act independently } \\
\text { but they are not independent in their decisions. They wait for the teacher's opinion } \\
\text { on what to do and / or how to do it. The teacher suggests the conditions for the } \\
\text { pupils. }\end{array}$ \\
\hline $\begin{array}{l}\text { COORDINÁATION } \\
\text { OF POINTS OF VIEW }\end{array}$ & $\begin{array}{l}\text { General framework: pupils are partly depended while using of teaching materials. } \\
\text { In most of their actions / activities, they ask for help, confront their actions with } \\
\text { the teacher's opinion, while the teachers' opinion is relevant to them. They use } \\
\text { teaching materials minimally. } \\
\text { Framework for concrete action: pupils act on the basis of the teacher's opinion and } \\
\text { consider it to be decisive. The teacher determines the specific process of the activity } \\
\text { and at the same time encourages the pupils to help him. Pupils are not supported } \\
\text { in independent decision-making. }\end{array}$ \\
\hline
\end{tabular}




\begin{tabular}{|l|l|}
\hline DECENTRATION & $\begin{array}{l}\text { General framework: pupils are dependent, fully dependent on the teacher's } \\
\text { decisions, waiting for his call and verbally and non-verbally giving instructions, } \\
\text { patterns and decisions. They wait for providing immediate feedback on the } \\
\text { correctness / appropriateness of their actions in the use of teaching materials. }\end{array}$ \\
$\begin{array}{l}\text { Framework of concrete action: the teacher determines the conditions of a } \\
\text { particular activity and the pupils act according to predetermined rules. The } \\
\text { teacher's position is decisive for the actions of the pupils. Pupils use teaching } \\
\text { materials dependently. }\end{array}$ \\
\hline
\end{tabular}

Constant comparison was realized as another phase of qualitative analysis of realized research. When applying the constant comparison method, it is not intended to verify universality, nor to confirm the causes or other input data. This procedure ensures the saturation of the necessary information. The aim of the constant comparison method is not to verify but to generate theory. The size and saturation of the information in the text is monitored until the saturation level is reached (Kolb, $2012 \mathrm{ln}$ : Kostrub, 2016).

Protocol No. 1 Significants of gender differences at mathematics lessons in teacher - pupil interaction (sample).

Source: author's own elaboration

\begin{tabular}{|c|c|c|}
\hline $\begin{array}{c}\text { Description of the teacher's actions in } \\
\text { the clasroom }\end{array}$ & Interaction fact & $\begin{array}{l}\text { Description of pupils' (girls/boys) } \\
\text { In the classroom }\end{array}$ \\
\hline $\begin{array}{l}\text { The teacher discusses proposals with the } \\
\text { pupils to implement the topic. } \\
\text { Suggestions provided by pupils are } \\
\text { recorded on the blackboard by the } \\
\text { teacher. The teacher accepts the } \\
\text { proposals of the procedures chosen by } \\
\text { the pupils. }\end{array}$ & $\begin{array}{l}U \leftrightarrows Z ̌ \\
\text { (GIRLS) }\end{array}$ & \multirow{2}{*}{$\begin{array}{l}\text { Pupils propose to the teacher to vote on } \\
\text { the suggestions so that they choose only } \\
\text { one solution to implement the chosen } \\
\text { topic. Pupils respect the voting rules they } \\
\text { agreed jointly. Pupils can make decisions } \\
\text { and think independently. Pupils can } \\
\text { propose solutions to solve the problem. } \\
\text { They can discuss how to solve the } \\
\text { problem. }\end{array}$} \\
\hline $\begin{array}{l}\text { The teacher connects the pupils with } \\
\text { brief instructions into lesson. He/she } \\
\text { encourages them with fast praise and } \\
\text { uses the models and columns they can } \\
\text { follow. However, the teacher accepts the } \\
\text { proposals they chose. }\end{array}$ & $\begin{array}{l}U \leftrightarrows Z ̌ \\
\text { (BOYS) }\end{array}$ & \\
\hline $\begin{array}{l}\text { The teacher does not create sufficient } \\
\text { space for the pupils to act independently. } \\
\text { He/she does not ask open questions to } \\
\text { students to develop a discussion, but } \\
\text { presents own knowledge gained from } \\
\text { experience. }\end{array}$ & $\begin{array}{l}U \leftarrow \rightarrow Z ̌ \\
\text { (GIRLS) }\end{array}$ & \multirow{2}{*}{$\begin{array}{l}\text { Pupils cannot decide and think } \\
\text { independently. Pupils cannot propose } \\
\text { solutions to solve the problem. They } \\
\text { cannot discuss how to solve the problem } \\
\text { They search in the real environment for } \\
\text { the symbols they have identified. They } \\
\text { present a possible process for the use of } \\
\text { teaching materials. They are not able to } \\
\text { evaluate and present their own use of } \\
\text { teaching materials. }\end{array}$} \\
\hline $\begin{array}{l}\text { The teacher does not provide } \\
\text { opportunity to pupils to experience } \\
\text { something in order for the pupils to fix } \\
\text { the new knowledge based on their own } \\
\text { experience. He/she does not give pupils } \\
\text { enough space to create their own ideas } \\
\text { related to the subject of interest. }\end{array}$ & $\begin{array}{l}\mathrm{U} \leftarrow \rightarrow Z ̌ \\
\text { (BOYS) }\end{array}$ & \\
\hline
\end{tabular}

\section{RESULTS}

The significance of the interaction (teacher - pupil) and its justification are the subject of research activities. If a teacher at mathematics lesson offers different activities for pupils to realize various activities and allows them to decide for themselves what activities they will realize in the activity and what teaching materials and techniques they choose and apply, the pupils provide to the teacher with several suggestions for the activity, 
they choose techniques and materials with the possibility of their application and suggestions for their use in activities within the activity, and mutually realize self-evaluation and evaluation of the realized activity.

The most serious research finding is the need for the teacher to respect the interests of pupils (girls / boys) in knowledge, to play roles, to perform various activities, and to respect the efforts to be independent based on the internal needs of pupils (girls / boys), learn, explore and discover new / unknown to them. At the same time, expect that the pupils (girls / boys) what they acquired / obtained, will be able to use for their own benefit and thus face problems. According to subjects of research, it is healthy to be aware of (self) confidence and sufficiency in the use of teaching materials. Likewise, it is important, as subjects of research point out, to prevent orders and prohibitions. Rather, pupils are offered choices (for which they are reasonably responsible and supported in its takeover) and are presented with appropriate proposals as well as the use of appropriate forms of creative creation - developing pupils' thinking. As subjects point out, independent pupils are happier, they do not need help always and in all situations. On the contrary, they can help others (they are partners) and thus become more independent: „By letting the pupils decide, think and act independently, they will become individuals who are independent, with their own opinion, able to communicate appropriately with others, and will also use "new" teaching materials at mathematics lessons, what is the basis for fair and diplomatic interpersonal relations and mutual cooperation. Subjects also point out that in the process of deliberately encouraging the use of learning materials, it is important that pupils are spontaneous and participate in the process of self-use of learning materials at math lessons in which they develop thinking, communication, creativity, motor skills, self-awareness, respect for oneself and others, the ability to adapt, to be able to make agreement and cooperate in joint activities within the activities, and to assert themselves optimally in the learning group (class). In addition to these socially necessary characteristics, teachers involved in research declare the importance of developing the appropriate courage to make independent decisions based on the interests and needs of pupils and others. In other words, "Let the students be themselves". From the perspective of teachers involved in the research, the effectiveness of the use of teaching materials is reflected in the fact that pupils are able to behave and act independently, when they are not commanded, or when no one observes or controls them (it is question of self-regulation). This does not mean that pupils "do what they want". On the contrary, this requires cooperation with pupils as equal partners in the demands of learning and development. Together with pupils, to develop rules and consistently insist to follow them and evaluate them to ensure an appropriate climate of acceptance and learning, as well as order during an organized and well-established daily program characterized by efficiency, regularity and accuracy (clear definition).

\section{CONCLUSION}

The erudition and competence of a teacher are factors that influence the teaching process in its entirety. The contemplating teacher distributes his / her attention both to his / her own teaching activity and to the learning activities of learners in which behavior is demonstrated, interests are revealed and mental, constructive activity, expectations and beliefs are encouraged. All of this is realized in a joint discursive and non-discursive activity of the teacher in the realization of teaching activities and school tasks - this is the core of teaching processes, which have a place in an institution called as a school. Teaching materials for teaching mathematics are essential tools of learning subjects, including primary school teachers. Recording data on papyrus, clay table, wooden board, magnetic board, white marker / ceramic board and interactive board is merely applying a simple recording technique (teaching aid). Teaching materials for teaching mathematics are a process in itself, providing that we wish to discover, to create (together) new perspectives of views on the curriculum / content / topic; to discuss and dispute about them.

\section{List of References}

[1] Abraham, J. (1989). Gender differences and anti-school boys. The Sociological Review, 37(1), 65-88.doi: 10.1111/1467-954X.ep5475471.

[2] Ammermüller, A., Dolton, P. (2006). Pupil-Teacher Gender Interaction Effects on Scholastic Outcomes in England and the USA. Center for European Economic Research. Discussion Paper No. 06-060.

[3] Attard, C., Curry, C. (2012). Exploring the Use of iPads to Engage Young Students with Mathematics. Mathematics Education Research Group of Australasia.

[4] Bisin, T., Verdier, A. (2001). The Economics of Cultural Transmission and the Dynamics of Preferences. Journal of Economic Theory, 97: 298-319. 
[5] Bonomo, V. (2017). Brain-Based Learning Theory. Journal of Education and Human Development, Vol.6, No.1, pp 27-43.

[6] Bruner, J. S. (1966). Toward a theory of instruction. Cambridge, MA: Harvard University Press.

[7] Buzhigeeva, M. I. (2004). Gender characteristics of children in the primary stage of instruction. Russian Education and Society, 46(4), 76-88.

[8] Carrier, S. J. (2009). Environmental education in the schoolyard: Learning styles and gender. The Journal of Environmental Education, 40 (3), 2-12. doi: 10.3200/JOEE.40.3.2-12.

[9] Carrington, B., Francis, B., Hutchings, M., Skelton, C., Read, B., \& Hall, I. (2007). Does the gender of the teacher really matter? Seven- to eight-year-olds' accounts of their interactions with their teachers. Educational Studies, 33(4), 397-413. doi: 10.1080/03055690701423580.

[10] Ciarrochi, J., Heaven, P. C. L., \& Davies, F. (2007). The impact of hope, self-esteem, and attributional style on adolescents, school grades and emotional well-being: A longitudinal study. Journal of Research in Personality, 41, 1161-1178. doi: 10.1016/j.jrp.2007.02.001.

[11] De Fruyt, F., Van Leeuwen, K., De Bolle, M., \& De Clercq, B. (2008). Sex differences in school performance as a function of conscientiousness, imagination and the mediating role of problem behavior. European Journal of Personality, 22(3), 167-184. doi: 10.1002/per.675.

[12] Deary, I. J., Strand, S., Smith, P., \& Fernandes, C. (2007). Intelligence and educational achievement. Intelligence, 35,13-21. doi: 10.1016/j.intell.2006.02.001.

[13] Dee, T. S. (2006). The why chromosone: How a teacher' s gender affects boys and girls. Education Next, 6(4), $1-7$.

[14] Demie, F. (2001). Ethnic and gender differences in educational achievement and implications for school improvement strategies. Educational Research, 43 (1), 91-106. doi: 10.1080/00131880110040968.

[15] Driessen, G. (2007). The feminization of primary education: effects of teachers' sex on pupil achievement, attitudes and behavior. The Review of Education, 53, 183-203. doi: 10.1007/s11159-007-9039-y.

[16] Duckworth, A. L., \& Seligman, M. E. P. (2006). Self-discipline gives girls the edge: Gender in self-discipline, grades, and achievement test scores. Journal of Educational Psychology, 98(1), 198-208. doi: 10.1037/00220663.98.1.198.

[17] Francis, B., Skelton, C., Carrington, B., Hutchings, M., Read, B., \& Hall, I. (2008). A perfect match? Pupils' and teachers' views of the impact of matching educators and learners by gender. Research Papers in Education, 23(1), 21-36. doi: 10.1080/02671520701692510.

[18] Gavora, P. (2008). Úvod do pedagogického výskumu. Bratislava: Vydavatel'stvo Univerzity Komenského.

[19] Gibb, S. J., Fergusson, D. M., \& Horwood, L. J. (2008). Gender differences in educational achievement to age 25. Australian Journal of Education, 52(1), 63-80.

[20] Gil Hernández, T. (2007). El Aprendizaje Comprensivo y Creativo a Partir de la Investigación-Acción Como Estrategia Didáctica Epistémica en la Educación Básica. Laurus - Revista de Educación. 13 (023), 11-35.

[21] Hicks, B. M., Johnson, W., lacono, W. G., \& McGue, M. (2008). Moderating effects of personality on the genetic and environmental influences of school grades helps to explain sex differences in scholastic achievement. European Journal of Personality, 22, 247-268. doi: 10.1002/per.671.

[22] Hilton, A. (2018). Engaging Primary School Students in Mathematics: Can iPads Make a Difference?. International Journal of Science and Mathematics Education, 16(1), 145-165.

[23] Holmlund, H., \& Sund, K. (2008). Is the gender gap in school performance affected by the sex of the teacher? Labour Economics, 15, 37-53. doi: 10.1016/j.labeco.2006.12.002.

[24] Hyde, J. S., Fennema, E., Ryan, M., Frost, L. A., \& Hopp, C. (1990). Gender comparison of mathematics attitudes and affect. Psychology of Women Quarterly, 14 (3), 299-324.

[25] Kemmis, S., McTaggart, R. (1982). The action research planner. Victoria Australia Deakin: University Press.

[26] Kostrub, D. (2016). Základy kvalitatívnej metodológie - ked'interpretované významy znamenajú viac ako vysoké čisla. Bratislava: Univerzita Komenského. 
[27] Lahelma, E. (2005). School grades and other resources: The "Failing Boys" discourse revisited. Nordic Journal of Women's Studies, 13(2), 78-89. doi: 10.1080/08038740500365374.

[28] Larkin, K. (2016). Mathematics Education and Manipulatives: Which, When, How?. Australian Primary Mathematics Classroom, 21(1), 12-17.

[29] Leeson, P., Ciarrochi, J., \& Heaven, P. C. L. (2008). Cognitive ability, personality, and academic performance in adolescence. Personality and Individual Differences, 45, 630-635. doi: 10.1016/j.paid.2008.07.006.

[30] Marsh, H. W., Martin, A. J., \& Cheng, J. H. S. (2008). A multilevel perspective on gender in classroom motivation and climate: Potential benefits of male teachers for boys? Journal of Educational Psychology, 100 (1), 78-95. doi: 10.1037/0022-0663.100.1.78.

[31] Matthews, J. S., Cameron Ponitz, C., \& Morrison, F. J. (2009). Early gender differences in self-regulation and academic achievement. Journal of Educational Psychology, 101 (3), 689-704. doi: 10.1037/a0014240.

[32] Meece, J., Bower Glienke, B., \& Burg, S. (2006). Gender and motivation. Journal of School Psychology, 44, 351-373. doi: 10.1016/j.jsp.2006.04.004.

[33] Meelissen, M., \& Luyten, H. (2008). The Dutch gender gap in mathematics: Small for achievement, substantial for beliefs and attitudes. Studies in Educational Evaluation, 34, 82-93. doi: 10.1016/j.stueduc.2008.04.004.

[34] Mills, M., Martino, W., \& Lingard, B. (2004). Attracting, recruiting and retaining male teachers: policy issues in the male teacher debate. British Journal of Sociology of Education, 25(3), 355-369.

[35] Moyer-Packenham, P., Baker, J., Westenskow, A., Anderson, K., Shumway, J., Rodzon, K., \& Jordan, K. (2013). A study comparing virtual manipulatives with other instructional treatments in third-and fourthgrade classrooms. Journal of Education, 193(2), 25-39.

[36] Pavlov, I. (2002). Profesijný rozvoj pedagogického zboru školy: námety na školocentrický a personocentrický model kontinuálneho vzdelávania učitel'ov. Prešov: Metodicko-pedagogické centrum.

[37] Preckel, F., Holling, H., \& Vock, M. (2006). Academic underachievement: Relationship with cognitive motivation, achievement motivation, and conscientiousness. Psychology in the Schools, 43 (3), 401-411. doi: $10.1002 /$ pits.20154.

[38] Resing, W. C. M., Bleichrodt, N., \& Dekker, P. H. (1999). Measuring personality traits in the classroom. European Journal of Personality, 13(6), 493-509.

[39] Sadker, M., \& Sadker, D. (2010). Failing at fairness: How America's schools cheatgirls. Simon and Schuster.

[40] Severini, E., Kostrub, D. (2018). Kvalitatívne skúmanie v predprimárnom vzdelávaní. Prešov: Rokus.

[41] Schacter, J., \& Jo, B. (2017). Improving preschoolers' mathematics achievement with tablets: a randomized controlled trial. Mathematics Education Research Journal, 29(3), 313-327.

[42] Simpson, A. W., \& Erickson, M. T. (1983). Teachers' verbal and nonverbal communication patterns as a function of teacher race, student gender, and student race. American Educational Research Journal, 20 (2), 183-198.

[43] Singer, J. (2015). The effects of iPad devices on elementary school students' Mathematics achievement and attitudes. Northeastern University.

[44] Skelton, C. (2003). Male primary teachers and perceptions of masculinity. Educational Review, 55(2), 195209. doi: 10.1080/0013191032000072227.

[45] Spender, D. (1982). Invisible women: The schooling scandal. London: Writers and Readers Publishing.

[46] Spinath, F. M., Spinath, B., \& Plomin, R. (2008). The nature and nurture of intelligence and motivation in the origins of sex differences in elementary school achievement. European Journal of Personality, 22,211-229. doi: $10.1002 /$ per.677.

[47] Stake, J. E., \& Katz, J. F. (1982). Teacher-pupil relationships in the elementary school classroom: teachergender and pupil-gender differences. American Educational Research Journal, 19(3), 465-471.

[48] Steinmayr, R., \& Spinath, B. (2008). Sex differences in school achievement: What are the roles of personality and achievement motivation? European Journal of Personality, 22, 185-209. doi: 10.1002/per.676. 
[49] Švec, Š., et al. (1998). Metodológia vied o výchove. Bratislava: Iris.

[50] UNESCO. (2005). EFA global monitoring report 2005: The quality imperative. Paris: UNESCO.

[51] UNESCO. (2000). Increasing the number of women teachers in rural schools: A synthesis of country case studies: South Asia. Bangkok: UNESCO Principal Regional Office for Asia and the Pacific.

[52] Volk, M., Cotič, M., Zajc, M., \& Starčič, A. I. (2017). Tablet-based cross-curricular maths vs. traditional maths classroom practice for higher-order learning outcomes. Computers \& Education.

[53] Walter D. (2018) How Children Using Counting Strategies Represent Quantities on the Virtual and Physical 'Twenty Frame'. Uses of Technology in Primary and Secondary Mathematics Education. ICME-13 Monographs. Springer, Cham.

[54] Younger, M., Warrington, M., \& Williams, J. (1999). The gender gap and classroom interactions: Reality and rhetoric. British Journal of Sociology of Education, 20(3), 325-341.

[55] Younger, M., \& Warrington, M. (1996). Differential achievement of girls and boys at GCSE: Some observations from the perspective of one school, British Journal of Sociology of Education17, 299-314.

[56] Zilcher, L., Svoboda, Z. (2019). Inkluzivní vzdělávání: Efektivní vzdělávání všech žáků, Praha: Grada

[57] Zilcher, L., Svoboda, Z. (2018). Proinkluzivní změny na školách formou strategického plánování, In Inkluzivní vzdělávání v souvislostech, PIzeň: ZČU, 16-21. 